Ann. Biol. anim. Bioch. Biophys., 1979, 19 (4 B), 1279-1288

\title{
Some relationships among germ, satellite and interstitial cells during chick gonad differentiation : A tissue culture study
}

\author{
par J. JORDANOV, Pavlina ANGELOVA \\ Institute of Morphology ot the Bulgarian Academy of Sciences, \\ ul. Acad. G. Bontchev bl. 3, 1113 Sofia, Bulgaria.
}

Summary. We have used a tissue culture technique in which female and male chick gonads of different ages, as well as fragments of them containing different cell populations, are cultured separately or in parabiosis, varying the composition of the culture medium. From the explant growth patterns observed, we have discussed the relationships among germ, satellite and interstitial cells, as well as the significance of these relationships in gonadal sex differentiation and germ cell development.

\section{Introduction.}

Firkef (1914), Swift $(1915,1916)$ and Brode (1928) have shown that the three major cell populations in the chick gonad - germ, satellite and interstitial cells - develop in both sexes during embryonic life. The chick gonad is therefore a suitable model for analyzing the relationships among these three cell types in order to study the factors controlling gonadal sex differentiation and the onset or arrest of meiosis in female or male germ cells.

Wolff and his collaborators carried out remarkable experiments on gonadal differentiation, achieving feminization of the male gonad with estrogen injections into male embryos, heterosexual grafts or in vivo and in vitro parabiosis of the gonads of both sexes. These experiments led to the conclusion that the interstitial estrogenproducing cells of the ovarian medulla might play an important role in the sex differentiation of the early ovary itself (Wolff and Haffen, 1965 ; Scheib and Haffen, 1974).

However, all attempts to masculinize the female chick gonad using similar methods, including androgen administration, were unsuccessful (Wolff and Haffen, 1965), thus indicating that testicular sex differentiation might be independent of the interstitial androgen-producing cells. The factors triggering or preventing meiosis are also unclear and have hardly been studied. The retention of the medullary germ cells in the left and the right ovary at a gonial stage, and their regression towards the end of embryonic life or a short time afterwards, are related to the above problems, and the factors involved in that process are also undefined. 
In our experimental approach to some of these questions, we have taken into consideration some differences in the chronological development of both the interstitial and the germ cells. Although data do not agree on the initiation of the steroidogenic function in the interstitial cells (Scheib and Haffen, 1974), it can be concluded that this function develops earlier in the ovary than in the testis. Our cytochemical and defailed electron microscopic studies have shown that the steroidogenic function develops in the ovary at about 7 to 8 embryonic days (ED), while it appears in the testis at about ED 11 to 12 (Angelova and Jordanov, 1975 ; Angelova and Bakalska, 1975 ; Jordanov et al., 1977, 1978). There is also a chronological difference in the period of enhanced germ cell proliferation, which occurs in the ovarian cortex between ED 9 and 14 and in the testis between ED 14 and 17 (Swift, 1915, 1916 ; Brode, 1928).

This study was carried out using a modified tissue culture technique. The data have been briefly reported elsewhere (Jordanov, 1974a, $b$; Jordanov and Angelova, $1974 a, b)$.

\section{Material and methods.}

Gonads were removed from White Leghorn or White Plymouth Rock $\times$ Cornish chick embryos on ED 8 to 16 . The tissue culture technique has been described previously (Jordanov, 1971). Briefly, the material is explanted in a drop of rooster plasma spread on the surface of a transparent celloidine, protein-permeable membrane placed with the explants upwards (in some cases, downwards) in the depression of a large excavated slide over a liquid culture medium. One to 3 whole organs or 3 to 6 fragments per culture were explanted. The standard medium contained calf serum and two kinds of egg yolk dialysates (protein-containing and protein-free) in the proportion of 1:1:2 (dialysates prepared according to Jordanov). Synthetic TCM 199 alone, proteinfree yolk dialysate alone or a mixture of both fluids in equal parts were also used as media. The explants grew more or less flattened on the membrane, and the small fragments or very young organs predominantly histotypically. The membrane was transferred into a fresh medium every 2 to 3 days.

After a few days to 2 weeks of culture, the explants, together with the membrane, were fixed in Carnoy, stained with Harris' hematoxylin, dehydrated in ethyl alcohols and cleared in cedar oil. The explants were microscopically examined in total preparations or in histological sections; in the second case the explants were removed from the membrane and embedded in paraffin. The following series of experiments was carried out using the corresponding explantation conditions.

Series A. - Whole 8 to 12-day old left ovaries or fragments of them were placed directly on the celloidin membrane (without plasma) over the three protein-free media mentioned (58 cultures).

Series B. - Cortical fragments of 9 to 13-day old left ovaries were cultured in a standard medium or TCM 199. Fragments of younger organs were obtained by tangential excision of the cortex. Older organs were previously bound in the hilus with a thread, then removed and treated with a 0.250 p. 100 trypsin solution for 25 to $30 \mathrm{~min}$, and finally drawn along the membrane with the cortex downwards, thus lea- 
ving fragments of simple cortex or those containing medulla on the membrane (total of 30 cultures).

Series C. - Small (mixed) fragments of 14-day old ovaries, treated or not with trypsin were cultured; the explants were turned downwards on day 2 of culture (15 cultures).

Series D. - Left 9 to 16-day old ovaries cultured in standard medium or in TCM 199 $(23+5$ cultures $)$; right 9 to 16 -day old ovaries cultured in the same media $(31+5$ cultures).

Series E. - Left 12 to 13-day old ovaries cultured in parabiosis with left 8 to 9-day old ovaries (10 cultures) or with right 8 to 9-day old ovaries (15 cultures).

Series F. - Left 8 to 10-day old testes cultured in parabiosis with left 11 to 14-day old ovaries (26 cultures) or with right 12 to 13-day old ovaries (17 cultures). One single testis was explanted between two ovaries or, in the case of the older ovaries, between the two halves of the ovary, at a distance of 1 to $3 \mathrm{~mm}$.

Series G. - Left 11 to 16-day old testes cultured in parabiosis with 9 to 10-day old left (34 cultures) or right (22 cultures) ovaries. One single ovary was explanted between two testes or between the two halves of a longitudinally cut testis.

\section{Results and discussion.}

Series A. - The ovary explants maintained in culture for 3 to 4 days, i. e. until a total age of 12 to 13 days in ovo and in vitro, showed good proliferation of the cortical oogonia which were frequently found in mitosis. In more advanced cultures at a total ovarian age of 17 to 18 days, a great number of cortical oogonia had progressed to zygotene and pachytene stages (PI. I, fig. 1). Mitotic oogonia were also still present, as well as oocytes just entering meiosis. This corresponded to the known asynchrony of the meiotic process in the chick ovary.

Wolff et al. $(1953,1960)$ explanted indifferent chick gonads in synthetic media and established good ovarian differentiation, but these authors did not observe the onset of meiosis in the germ cells, obviously because the ovaries in their cultures had not reached a total age of more than 14 days. Our results indicated that meiosis in the left ovary could initiate and proceed to advanced stages if the influences of other organs upon the ovary were avoided by omitting serum and other protein-containing fluids from the medium. This would imply that the factors controlling meiotic prophase are within the ovary itself.

Series B. - In 8 to 9-day old cultures, more than 50 explants, mainly from the older ovaries, were found to be purely cortical fragments according to their composition. The germ cells in all of them, having a total age of 18 to 19 days, were arrested at the gonial stage (PI. I, fig. 2). In contrast, in the rare mixed explants also containing a medullary component, the germ cells had passed through meiosis as in series $A$. The reason for meiotic arrest in the cortical explants might be the absence of the meiosis-inducing interstitial cells of the medulla with their estrogens. Further experiments seem to confirm this assumption. 
When the ovarian fragments in series $A$ and $B$ were explanted on the superior surface of the celloidin membrane, the following pattern was seen : the oogonia pro. liferated into the growth area and then passed into oocytes only if a layer of satellite cells was previously formed between them and the membrane (PI. I, fig. 3).

Series $C$. - When the ovarian fragments were grown on the inferior surface of the membrane, the germ cells in contact with the membrane proliferated, being covered on the medium side with satellite cells. Since we observed this phenomenon using another culture method (Jordanov et al., 1966), our previous data are confirmed and extended. They show that even at early developmental stages, the germ and satellite cells are closely related morphofunctionally, the satellite cells protecting the germ cells and probably acting as a metabolic mediator between them and the environment.

Series D. - Due to intense germ cell multiplication, the left and right ovaries showed medullary cord thickening at a total (in ovo and in vitro) age of 17 to 18 days. The interstitial cells in the medulla were also well developed. At the same time, the germ cells of the left ovary cortex had progressed through meiosis. In more advanced cultures medullary oogonia in both the left and right ovaries had also started meiotic prophase, reaching pachytene and even diplotene, at a total age of 23 to 25 days (PI. I, figs. 4, 5). The latter phenomenon was also observed in ovaries cultured in TCM 199 and surviving until the same age.

These findings do not agree with those of Wolff and his collaborators who described spontaneous testicular transformation of the avian right ovary and of the left ovary medulla when cultured (Wolff and Haffen, 1965). These authors probably observed what appeared to be a transformation, as they mention « sterile tubules ». Grassi-Milano and Pitini (1977) recently reported that they did not find this transformation in chick ovary cultures.

Series D data show that the arrest of medullary germ cells at the gonial stage in in vivo ovarian development could be determined by a local factor, or more possibly by an extragonadal one. The elimination of the action of this factor under in vitro

\section{PLATE 1}

FIG. 1. - Fragment of an 8-day old left ovary after 8-day culture in TCM 199. Total preparation. $\times 500$.

FIG. 2. - Cortical fragment of a trypsinized 12-day old left ovary after 8-day culture. Total preparation. $\times 800$.

FIG. 3. - Fragment of a 13-day old left ovary explanted on the superior surface of the celloidin membrane. The oocyte layer $(O)$ is focused and the satellite cell layer $(S)$ beneath it is hardly perceptible. Total preparation. $\times 80$.

FIG. 4. - 10-day old left ovary after 13-day culture. Oocytes in the cortex (C) at advanced stages of meiotic prophase. Oogonia and oocytes in the medulla (arrows) af leptotene and zygotene. Histologic section. $\times 200$.

FIG. 5. - 16-day old right ovary after 12-day culture. A cord with germ cells at advanced stages of meiotic prophase. Total preparation. $\times 800$. 
$-*, 9,3$

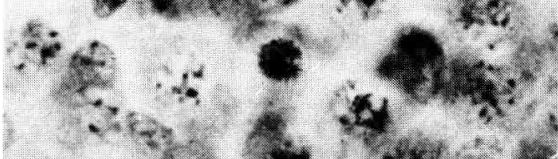
3... 40.4 a. 020 $-70 \div 9$ Qindt, $* 2$

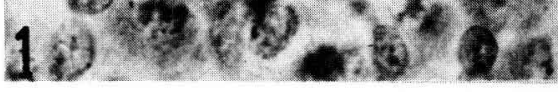
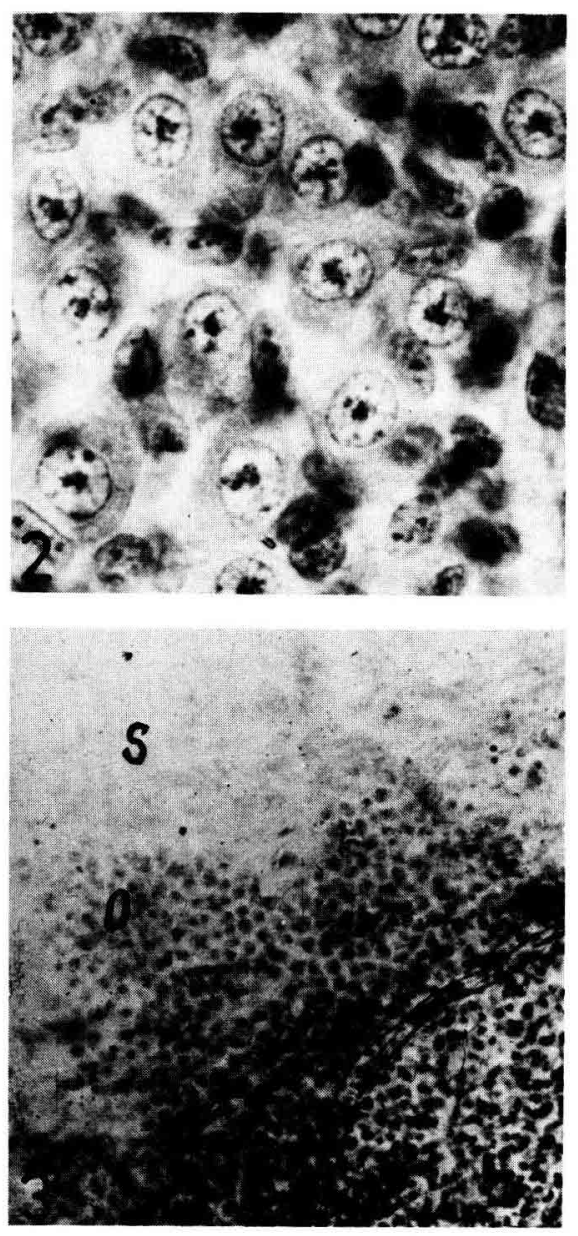

Ro:30.7\% 0.0 .0 .0

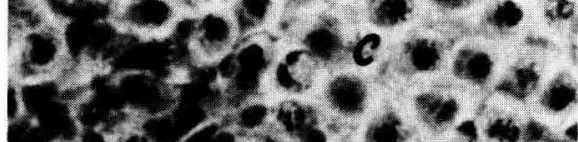

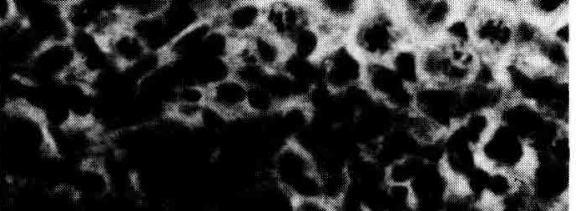

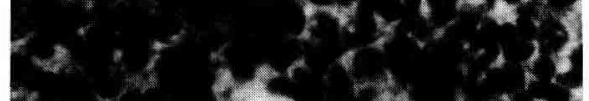

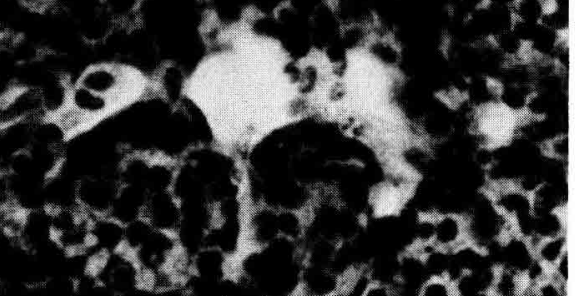

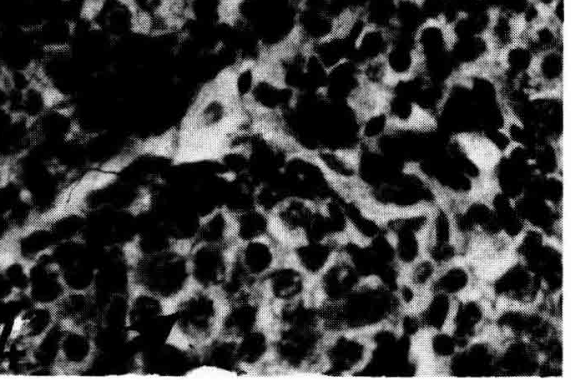

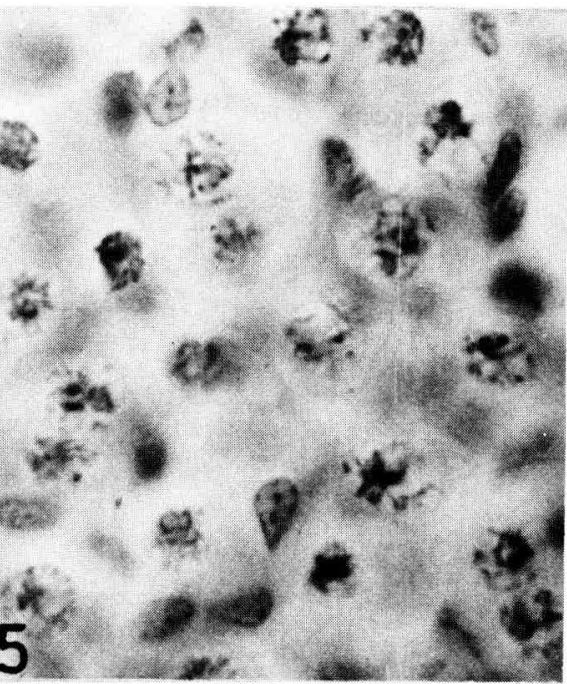


conditions, and/or the easy access which interstitial cell estrogens would have to the medullary oogonia, might permit these hormones to exercise a meiosis-inducing effect upon the oogonia. It is to be wondered why they enter meiosis later than the cortical oogonia.

The development of ovarian interstitial cells starts from ED 7 to 8 (Jordanov ef al., 1977, 1978). Swift (1915) has shown that the cortical germ cells multiply intensely between ED 9 and 14 before they begin meiosis. We observed the same sequence and continuation of both these periods during culture (series A). If the onset of meiosis depends on interstifial cell estrogens, it is evident that interstitial cell action is initially expressed by a stimulation of germ cell mitotic activity. Germ cells probably pass through a definite number of genetically programmed mitoses before beginning meiosis. In medullary germ cells of the left and right ovaries, the process of multiplication in vitro is obviously slower and more prolonged, thus causing meiosis to begin later in these cells.

Series E. - Meiosis always began in the cortical germ cells of the younger left ovaries at a total age of about 14 days in ovo and in vitro. In the germ cells of the younger right ovaries, this occurred at a total age of 18 to 19 days. Thus, the older left ovaries could not accelerate or delay the in vitro development of either type of germ cell, which had to go through a more or less prolonged period of multiplication before meiosis was initiated.

Series F. - About 60 p. 100 of the testes explanted in parabiosis with older, hormonally active left ovaries and about 70 p. 100 of the testes explanted in parabiosis with older right ovaries showed evident feminization. As early as culture day 3 to 4 , longitudinal corticalization of the testes was seen which comprised one-fourth to one-third of the width of the organ in the following days (PI. II, fig. 1). Histological

\section{PLATE II}

FIG. 1. - 9-day old testis explanted befween 2 halves of a 12-day old ovary offer 12-day culture. Corticalization (C) of the testis. Supravital observation. $\times 50$.

FIG. 2. - Histologic section of the same testis. Some germ cells in the cortex are at leptotene (arrows). The rest of the testis shows fubular structure. $\times 500$.

FIG. 3. - 8-day old testis explanted between 2 halves of 12-day old left ovary after 12-day culture. Germ cells of seminiferous cords have entered meiotic prophase. Total preparation. $\times 800$.

FIG. 4. - 9-day old ovary explanted between two 12-day old testes; only one testis (T) is seen at left. The ovarian medulla $(M)$ has a fubular structure. A part of the ovarian cortex is visible at the top. Histologic section. $\times 80$.

FIG. 5. - The same as figure 4 but higher magnification $(X 500)$. A fubule of the masculinized ovarian medulla.

FIG. 6. - 9-day old right ovary explanted befween fwo 12-day old testes. Tubules of the masculinized ovary. Histologic section. $\times 500$. 


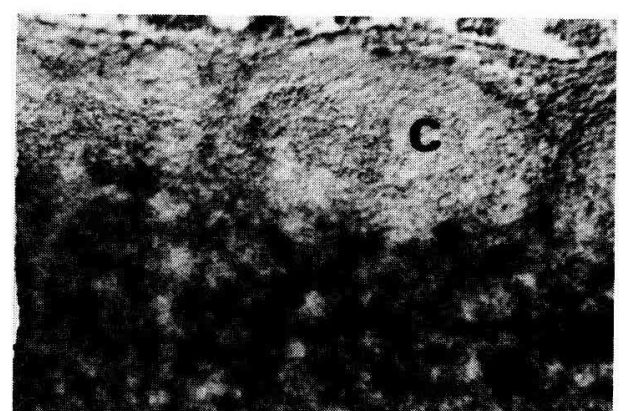

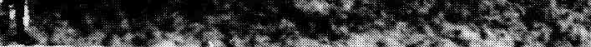
$=-20 .+2$ 0.03 .0$. 5.52021 - 02 anas $102-1,-1=$ $-2+5-12$

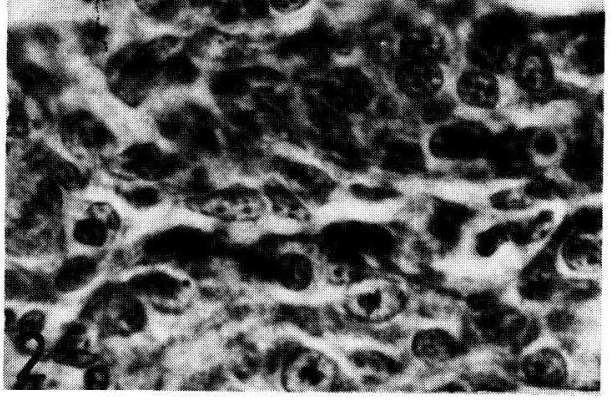

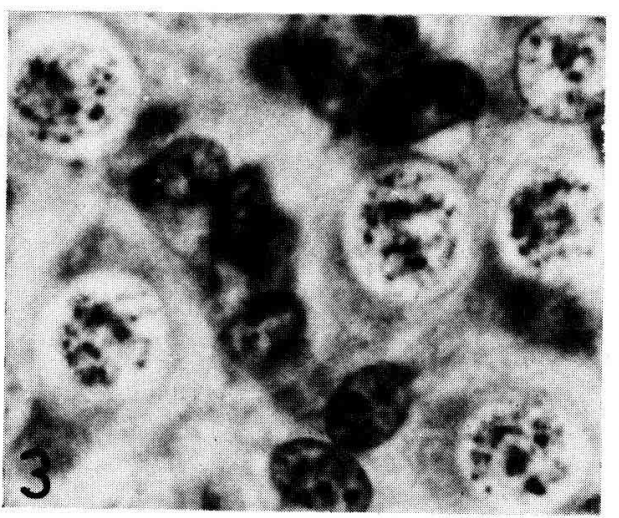

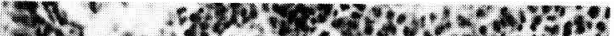

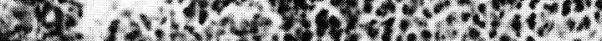
sis

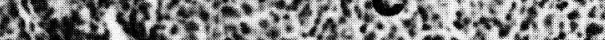
ใ. s.t.

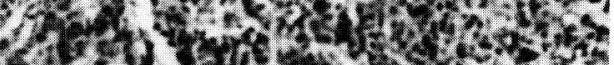

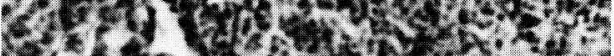

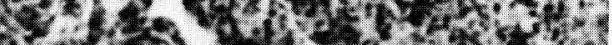

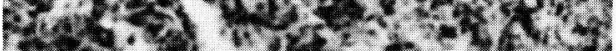

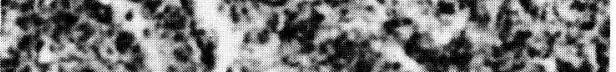
cass.

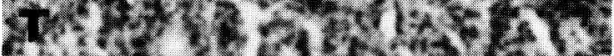
c.

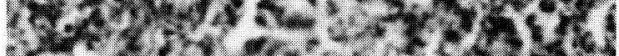

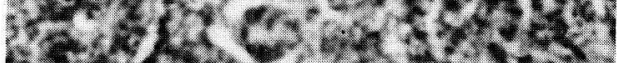

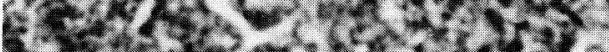

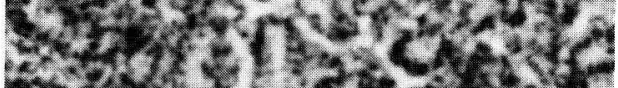

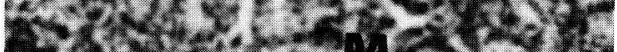
ard

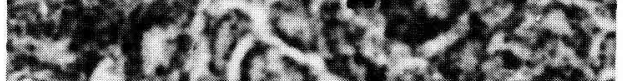

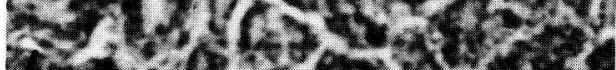

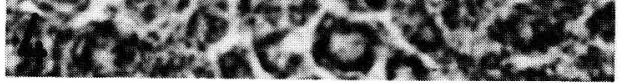

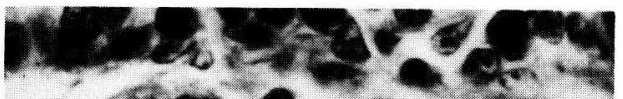

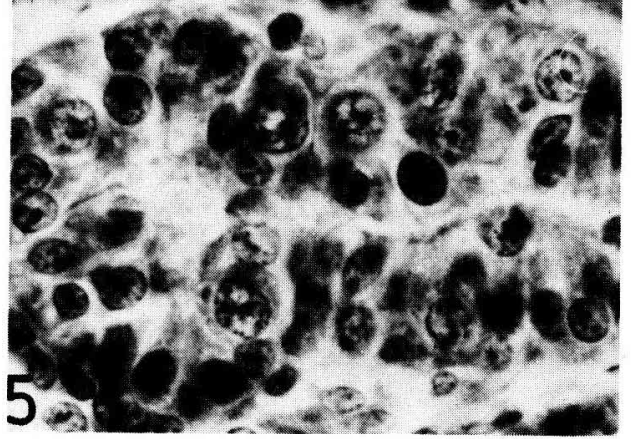

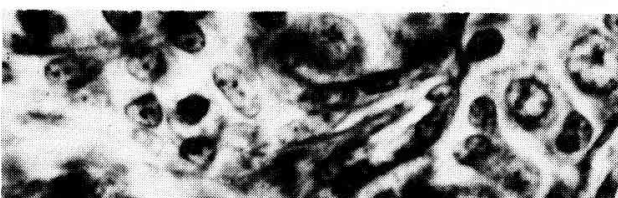

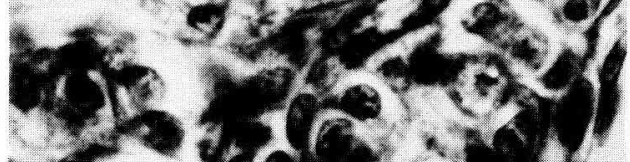

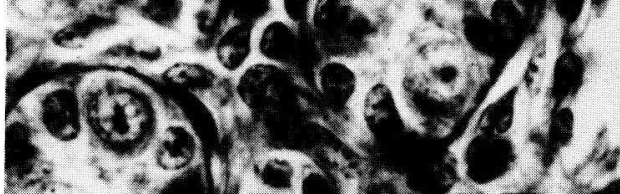

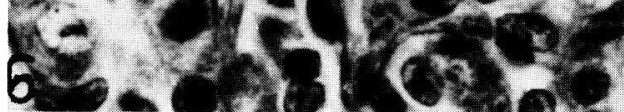


examination revealed the presence of numerous germ cells with scattered satellite cells in the induced cortex of the testes at a total age of 18 to 19 days. In 5 left ovary and 3 right ovary cultures, where the testis remained healthy until 19 to 23 days, the germ cells in the deeper layers of the induced cortex had entered leptotene, and later zygotene. The rest of the testis presented a tubular structure. Thus, the general appearance of the organ was that of an ovotestis (PI. II, fig. 2). In 8 other cultures the young testis grew histotypically between the two older ovaries, and its seminiferous cords were filled with germ cells. In 3 of these cultures containing a 20-day old testis, the seminiferous tubule germ cells had also entered meiotic prophase (PI. II, fig. 3).

As regards in vitro feminization of the testis, our results correspond to the wellknown data of Wolff and his collaborators (Wolff and Haffen, 1965). However, in contrast to their data on the in vivo feminized testis, those authors reported no meiosis in the germ cells of the in vitro feminized testis, probably owing to the short culture time. Our parabiotic explants showed that testicular germ cells could enter meiosis after passing through a more prolonged period of proliferation, as the ovarian medullary oogonia in vitro (series $D$ ). It is reasonable to assume that the interstitial estrogen-producing cells of the co-cultured ovaries initiated meiosis. The already developing interstitial cells of an older testis would permit the meiotic process to evolve only in the induced cortex germ cells. The seminiferous tubule germ cells of a younger histotypically growing testis were also affected by the process, probably because ovarian estrogens were more easily accessible.

Series G. - The younger ovaries, having relatively weak hormonal activity, underwent medullary cord transformation under the influence of co-cultured, hormonally-active testes. Already after 4 to 5 days, and more distinctly after 7 to 8 days, 80 p. 100 of left ovaries and 60 p. 100 of right ovaries evidenced a testicular structure of the medullae. Histological sections showed luminized cords (tubules) lined with satellite cells and a number of basally located gonia. The left ovary cortex was preserved but appeared underdeveloped (PI. II, figs 4, 5, 6).

It is evident from the series $G$ results that the embryonic chick ovary medulla has been experimentally masculinized. It is known that the cords of the ovarian medulla are homologous to the seminiferous cords of the testis. The fact that the co-cultured testes possessed well developed interstitial cells appears to indicate that their androgens play a role in ovarian masculinzation. The failure of previous experiments to masculinze the embryonic chick gonad may be explained by the fact that asynchrony of gonadal interstitial cell development in the two sexes was not taken into consideration (see Introduction).

It has recently been observed (Guichard et al., 1977 ; our unpublished data) that estrogens and androgens are simultaneously produced by both female and male chick gonads with the corresponding prevalence of one hormone. This prevalence appears to cause the feminization and masculinization observed in our parabiotic cultures. It may also regulate in ovo the sex differentiation of both male and female gonads as well as the development of their germ cells.

4th Workshop on "Development and maturation of the reproductive organs and functions » Luynes, France, octobre 1978. 
Résumé. On a étudié les relations entre les cellules germinales, satellites et interstitielles dans les gonades embryonnaires du Poulet, cultivées in vitro. On a explanté des gonades indépendamment ou en parabiose hétérosexuelle, aussi bien que des fragments de gonades de compositions cellulaires différentes. La prolifération des ovogonies corticales de l'ovaire gauche et leur transformation en ovocytes ont lieu en culture sur milieu nutritif sans protéines, en même temps que ces processus se développent in ovo. Ceci montre que les facteurs initiant la méiose sont présents dans l'ovaire lui-même. Les ovogonies dans des fragments de cortex ovarien prélevé précocement ne subissent pas une transformation en ovocytes in vitro. Les ovogonies médullaires des ovaires gauche et droit entrent in vitro en préméiose après une période d'activité mitotique. D'autre part la medulla des ovaires gauche et droit, cultivée en parabiose avec des testicules plus âgés, subit une transformation testiculaire. Ces dernières observations sont interprétées comme signifiant une intervention des cellules interstitielles et de leurs hormones dans la différenciation sexuelle de la gonade embryonnaire et dans l'évolution des cellules germinales.

\section{References}

ANGELOVA P., JORDANOV J., 1975. Histochemical and experimental studies on the steroidogenesis of the right embryonic chick ovary. Folia anat. lugosl., 4, 29-34.

ANGELOVA P., BAKALSKA-NESHEVA M., 1975. Histochemical studies on embryonic chick testis with regard to steroidogenesis. Folia anat. lugosl., 4, 35-40.

BRODE M. D., 1928. The significance of the asymmetry of the ovaries of the fowl. J. Morph. Physiol., 46, $1-41$.

GRASSI-MILANO E., PITINI A. M., 1977. Differentiation of ovaries and testes of chick embryos in organ culture. Acta embryol. exp., 1, 33-40.

GUICHARD A., CEDARD L., MIGNOT Th.-M., SCHEIB D., HAFFEN K., 1977. Radioimmunoassay of steroids produced by cultured chick gonads : differences according to age, sex and side. Gen. comp. Endocrin., 32, 255-265.

FIRKET J., 1914. Recherches sur l'organogenèse des glandes sexuelles chez les oiseaux. Arch. Biol., 29, 201-351.

JORDANOV J., 1971. Sur la culture des tissus et des blastodermes par une méthode modifiée de membranes perméables. C. R. Assoc. Anał., 146, 505-531.

JORDANOV J., 1974a. Certains rapports entre les cellules germinales, satellites ef interstitielles d'ovaire embryonnaire du poulet en culture in vitro. C. $R$. Acad. bulg. Sci., 27/9, 1283-1286.

JORDANOV J., 1974b. Entrée en préméiose des cellules germinales du testicule embryonnaire du poulet, féminisé in vifro sous l'influence d'un ovaire embryonnaire du poulet. $C$. R. Acad. bulg. Sci., 27/10, 1443-1446.

JORDANOV J., ANASTASSOVA-KRISTEVA M., HADJIOLOFF A. I., BOYADJIEVA-MICHAILOVA A., 1966. Zur Biologie des Sexualgewebes. Il. In vitro-Züchtung des Sexualgewebes von Hühnerembryonen. Acta morph. Acad. Sci. hung., 14, 3-4, 211-226.

JORDANOV J., ANGELOVA P., 1974a. Différenciation des ovogonies médullaires en ovocytes d'ovaires du poulet cultivés in vitro. C. R. Acad. bulg. Sci., 27/9, 1287-1290.

JORDANOV J., ANGELOVA P., 1974b. Masculinisation des ovaires embryonnaires de poulet, cultivés in vitro en parabiose avec des testicules embryonnaires. C. R. Acad. bulg. Sci., 27/10, 1447-1450.

JORDANOV J., ANGELOVA P., BOYADJIEVA-MICHAILOVA A., BAKALSKA-NESHEVA M., 1977. Recherches au microscope électronique sur le développement des cellules stéroïdogènes dans les gonades embryonnaires du poulet. C. R. Acad. bulg. Sci., 30/10, 1491-1494.

JORDANOV, J., ANGELOVA P., BOYADJIEVA-MICHAILOVA A., BAKALSKA-NESHEVA M., 1978. Ultrastructure of developing interstitial cells in chick embryonic gonad in relation to their genesis and steroidogenic function. Zschr. mikr.-anat. Forsch. (in press).

SCHEIB D., HAFFEN K., 1974. La glande interstitielle de l'oiseau : différenciation, évolution et potentialités sécrétrices. Année biol., 13, 197-212. 
SLUITER J. W., 1940. Die Cyłologie des Hühnereies während der ersten Phasen der Ovogenese. I, II. Protoplasma, 34, 393-458.

SWIFT Ch. H., 1915. Origin of the definitive sex-cells in the female chick and their relation to the primordial germ cells. Amer. J. Anat., 18, 441-470.

SWIFT Ch. H., 1916. Origin of the sex-cords and definitive spermatogonia in the male chick. Amer. J. Anat., 20, 375-410.

WOLFF Et., HAFFEN K., 1965. Germ cells and gonads. Chapter 17, 696-743. In WILLMER E. N. Cells and tissues in culture. Vol. 2, Acad. Press, London.

WOLFF Et., HAFFEN K., KIENY M., WOLFF Em., 1953. Essais de culłures in vitro d'organes embryonnaires en milieux synthétiques. J. Embryol. exp. Morph., 1, 55-84.

WOLFF Et., HAFFEN K., DIETERLEN F., 1960. Influence des états nutritionnels sur la différenciation et le fonctionnement des glandes endocrines embryonnaires. Ann. Nutr. alim., 14, B11-B20. 